\title{
Skull and cross words
}

\section{How the discovery of an ancient American skeleton set science against law.}

\author{
Riddle of the Bones: Politics, \\ Science, Race, and the Story of \\ Kennewick Man \\ by Roger Downey \\ Copernicus: 2000.216 pp. $\$ 25, £ 17$
}

\section{Simon Conway Morris}

In his famous work Democracy in America, first published in 1835, the French political scientist Alexis de Tocqueville wrote, "I thought that the English constituted the most serious nation on the face of the Earth, but I have since seen the Americans and have changed my mind". Nothing much seems to have changed in the intervening 160 years, at least to judge from this book, which documents with painful clarity the continuing circus that passes, at least in some quarters, for American life. To the indigenes no doubt it is all terribly important, but, viewed remotely, a rather different image swims into view: the all-too-familiar story of vaunting ambition, mad bureaucracy, political correctness and far, far too many lawyers, all snugly cemented by the glue of mutual suspicion and distrust.

Kennewick Man joins that long succession of archaeological finds that have had imposed on them cultural burdens and assumptions that far outstrip any legitimate reading of the evidence, which as often as not is thin in the extreme. The discovery of a partial skeleton by two teenagers wading in the shallows of the Columbia river was swiftly followed by its appropriation by a local archaeologist, one Jim Chatters.

Like various other characters that litter the pages of Riddle of the Bones, Chatters is not described in exactly glowing terms by Roger Downey. But he is first on the scene and gives the juggernaut its initial push. Radiocarbon dating soon proves Kennewick Man to be satisfactorily old, and there is intriguing evidence of a stone spear-point embedded in the pelvis. The sensation, however, lies in Chatters' examination of the skull. What emerges, as Chatters makes a series of frantic notes, is not an ancient or palaeo-Indian, a poignant relic of the last great human diaspora that led to the overrunning of the Americas. Instead, against all expectation, features of the skull appear, incredibly, to be 'Caucasoid', that is, most similar to a 'pre-modern European'.

Now the juggernaut begins to pick up speed, and the first hurdle seems to be easily surmounted. The skeleton was found on federal land, under the jurisdiction of the US Army Corps of Engineers. Their hallmark is one of unrestrained hydraulic enthusiasm, with a principal contribution to the Ameri-

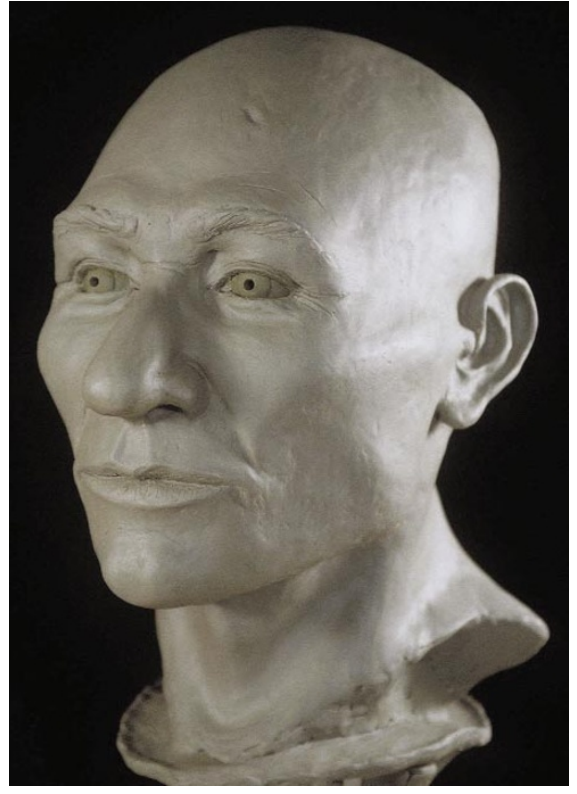

Origins of Kennewick Man: his unexpected 'Caucasoid' features made him a coveted prize.

can landscape being the erection of innumerable dams, irrespective of the mounting evidence for resultant environmental mayhem. A force to be reckoned with, but in any event Chatters' conveniently postdated excavation permit is swiftly obtained.

Things begin to unravel, however, at the next obstacle, which arises in the form of NAGPRA, the innocuous acronym for the 1990 Native American Graves Protection and Repatriation Act. Chatters' dispatching of a bone for radiocarbon dating, and thereby at least the partial destruction of the skeleton, was, as he should have known, a potentially serious mistake. Set up after years of effectively unrestricted archaeological excavation of Indian sites - looting, if you prefer - and the amassing of skeletons and artefacts in museums across the United States, NAGPRA was a well-meant but muddled and inconsistent piece of legislation designed to restore some semblance of dignity to the religious and cultural sensitivities of North America's original inhabitants.

The catch, of course, is that, for all intents and purposes, much of Indian history will remain forever irrecoverable unless it is subjected to scientific analysis. Almost inevitably, Kennewick Man, 'Caucasoid' or not, was now inextricably caught up in the turmoil of archaeological and museum politics, legal battles, Indian rights and the elephantine process of federal bureaucracy. Few of the characters depicted emerge with much credit as e-mails and telephones hum with acerbic demands and face-saving manoeuvres, steadily enmeshing an increasingly wide circle of individuals.

The cast is large, and Downey takes the narrative at a spanking pace - larded with folksy asides — that leaves the reader breathless to discover the final denouement. It slowly becomes clear, however, that, despite its tragicomic tone, the real target of Riddle of the Bones is not the various twists and turns of the American legal system, nor the Odinworshipping Asatru Folk Assembly, who greet Kennewick Man as a useful prop for their white supremacist world-view, or even the genuine ambiguities of Indian ownership, physical or spiritual, of archaeological remains that conceivably in reality derive from some long-vanished tribe or nation. Rather, as I read this book, it is as much to do with our, that is the West's, increasingly ambiguous attitude towards 'Science' with abig S.

Downey's views are marred by some garbled sections, not least the supposition that mitochondria were once virus-like, but, despite a broad sweep of current concerns, the underlying tenor is an uneasy mixture of relativist belief that ultimately nothing can really be known and a misplaced mathematics-envy that presupposes that only terribly clever people can really understand science. Downey's confusion of values is clear enough when, in self-contradictory style, he writes of one method (analysing teeth) as looking "behind the firm façade of numbers, charts and diagrams", while a little later he laments that "statistical thinking ... is beyond the capacities of many anthropologists". But he then continues, "They must, like the rest of us, take such results on faith, trusting to others more deeply indoctrinated to raise an alarm should the methodology or results seem dubious". Façades, indoctrination?

But, for all that, Downey deserves neither our scorn nor our condescension, because it is only in the last few pages that his message suddenly crystallizes. We never really learn who or what Kennewick Man was, or still is, but in his conclusion, reached as he sits perched on a spot known as Jump Off Joe, Downey achieves a near-mystical vision of combined paradoxes - continuity and aloneness, faith and knowledge - that reminds us that, for all the antics associated with Kennewick Man, where we came from and why we matter are genuinely important questions that science alone is ill-equipped to answer.

Simon Conway Morris is in the Department of

Earth Sciences, University of Cambridge,

Downing Street, Cambridge CB2 3EQ, UK. 